\title{
Kırsal Sürdürülebilirlik Bağlamında Geleneksel Köy Evlerinde Kullanılan Toprak Esaslı Yapı Malzemelerinin Incelenmesi
}

\author{
Mustafa ÖZGÜNLER* \\ Mimar Sinan Güzel Sanatlar Üniversitesi, Mimarlık Fakültesi, Mimarlık Bölümü, 34427, istanbul, Türkiye. \\ *e-mail:ozgunlerm@gmail.com \\ Öz \\ Son yıllarda inşaat endüstrisinde özellikle yapı malzemelerinin üretiminde ve kullanımında harcanan yüksek \\ enerjinin yol açtığı küresel ısınma sorunu tüm dünyada ciddi bir tehdit haline gelmiştir. Bu nedenle bir süredir \\ çevreye zarar vermeyecek yenilenebilir enerji kaynakları arayışı önem kazanmıştır. Bununla birlikte özellikle \\ yapım endüstrisinde sürdürülebilir yapım sistemleri ve ekolojik malzeme kullanımına yönelik bir çok atılım \\ gerçekleşmiştir. Bu bağlamda düşünüldügünnde günümüze kadar gelebilmiş geleneksel yapılarda kullanılmış olan \\ geleneksel yapı malzemelerine ilgi artmıştır. Bu malzemelerin düşük enerji harcayarak üretilmeleri ve \\ uygulandıkları yapıların çevreye dost ve kullanıcı konforuna uygun olmaları günümüzde dahi cazibelerini \\ arttırmaktadır. Bu görüşü destekleyecek bir çok bilimsel çalışma yapılmış ve yapılmaktadır.
}

Bu çalışmada, geleneksel yapı malzemesi olarak bir çok kültürde kullanılmış olan toprak esaslı malzemelerin sürdürülebilirliği ele alınmış bu amaçla çeşitli laboratuvar çalışmaları yapılmıştır. Mimar Sinan Güzel Sanatlar Üniversitesi BAP birimi tarafından desteklenen Köyünü Yaşat Projesi kapsamında Bilecik ili Gölpazarı ilçesinde Tongurlar Köyü'nde bulunan geleneksel yapılar araştırılmış, bu yapılarda kullanılmış olan toprak esaslı yapı malzemeleri çalışılmıştır. Bu çalışmanın yapılmasındaki temel amaçlar; kırsal sürdürülebilirlik bağlamında geleneksel yapıların özgün malzemeleri ile sürdürülebilirliğinin sağlanması ve toprak esaslı malzemelerin ekolojik değerlerini ön plana çıkartmaktır.

Anahtar Kelimeler: Toprak malzeme, kerpiç, geri dönüşüm, sürdürülebilirlik

\section{A Research on Vernacular Earth Based Materials for the Purpose of Sustaining Rural Architecture}

\begin{abstract}
In recent years, the global warming problem caused by the high energy consumed in the construction of building materials has become a serious threat all over the world. For this reason, the search for renewable energy sources that will not harm a sustainable environment has gained importance. However, there have been many breakthroughs in sustainable construction systems and the use of ecological materials, especially in the construction industry. In this context, interest in traditional building materials, which have been used in conventional structures that have come up to daylight, have increased. The fact that these materials are produced with low energy consumption and the structures made with them, are suitable for the friendliness of the environment and the comfort of the user increases their attractivity even today. A lot of scientific research has been done for a long time and is still being done to support this view.
\end{abstract}

In this study, the sustainability of earth-based materials used in many cultures as a traditional building material was discussed and various laboratory studies were carried out for this purpose. The earth based building materials used in the village of Tongurlar in the town of Gölpazarı in Bilecik province were researched and were studied. The main objectives of this study are; ensuring the sustainability of traditional buildings with their original materials in the context of rural sustainability and bringing the ecological values of earth-based materials to the forefront.

Keywords: Earth-based material, adobe, recycling, sustainability 


\section{Giriş}

Sürdürülebilirlik, ekoloji gibi kavramlar günümüzde yalnızca mimari alanda değil pek çok disiplinde kendine yer edinmiştir. Günümüzde gelecek ile ilgili oluşan kaygılar dolayısıyla bu konulara artan eğilim pek çok çalışmayı beraberinde getirmiş̧ir. Yapılan çalışmalar esnasında "Gerçek ekolojik bina nedir?" sorusunun bir cevabı olarak yapı stoğumuzun hala büyük bir kısmını oluşturan ve geleneksel kültürü taşıyan köy evlerinin düşünülmesi ile başlayan süreç, kırsal alanda kalkınmaya destek olabilecek bir model gerekliliğini ortaya koymuştur.

Kırsal alanlar, tarihten gelen farklı inanç ve yaşam alışkanlıklarını, bulundukları coğrafyadaki iklim verilerini ve yerel yapı malzemelerini kullanma geleneğini birleştiren çok zengin bir yapı çeşitliliğini bünyesinde barındırmaktadır. Anadolu'daki son 30 yıllık dönem incelendiğinde kırsal alanlardaki yerleşim dokusunun, yerel mimari özelliklerin ve yerel halkın ihtiyaçları göz önünde bulundurulmadan, bölgeye ve kültüre aykırı gerçekleşen yapılaşmalar sonucu doğal ve yapılı çevre mirasının bozularak yok olduğu gözlemlenmektedir. Kentsel odaklı yaşam biçimlerinin yaygınlaşması kırsal yapılı çevrenin, dolayısıyla da konut dokusunun kalitesini olumsuz etkilemektedir. Kırsal yerleşimlerin dokusu ile zengin ve çeşitli kırsal yapı yapma sanatı ve kültürü, modern yaşamın getirdiği aşırı tüketim ve kitle üretim biçimlerinin tehdidi altındadır, (Arpacıoğlu, 2016).

İnşaat endüstrisi tüm dünyada lokomotif sektör olarak görülmektedir. Bu endüstrinin yılda \%30 oranında karbondioksit salınımı yaptığı belirtilmektedir. Nüfus arttıkça yapım faaliyetleri de artmaktadır. Bu yapı intiyacı nedeniyle artan inşaat faaliyetlerinin çevreye verdiği zararlar da artmaktadır. Bu nedenle bu alanda sürdürülebilirlik ilkelerinin benimsenmesi dünyanın geleceği açısından çok büyük önem taşımaktadır, (Ngowi, 2001, ). Özellikle yapı malzemelerinin üretiminde ve kullanımında taşıdığı ekolojik değerler çok büyük bir öneme sahiptir.

Bu nedenle ekolojik değeri yüksek yapı malzemelerinin kullanımı global sürdürülebilirlik açısından büyük katkı sağlayacaktır. Bu bağlamda düşünüldüğünde geleneksel malzeme olarak bilinen toprak esaslı malzemeler son derece önemli bir yere sahiptir, (Arpacıoğlu, 2006; Koçu, 2006).

Geleneksel malzemeler "ekolojik, yeşil ve çevre dostu" olarak adlandırıır, ancak çağdaş malzemeler genelde üretimleri için çok enerji harcanan ve geri donuşum imkanı hiç olmayan ya da az olan malzemelerdir, (Torgal vd., 2008; Morton vd., 2005).

Literatürde, sürdürülebilir malzeme olarak adlandırılan malzemelerin sahip olduğu özellikler:

- Yenilenebilir, doğal enerji kaynaklarını kullanma,

- Geri dönüşümlü (re-cycle), tekrar kullanılabilir (re-use;) olma,

- Üretiminde, kullanımında ve tüketiminde enerjiyi az kullanan, çevreye duyarlı olma,

- İyi ısı yalıtım özelliğine sahip olma,

- Insan sağlığına zararlı emisyonlara sahip olmama,

- Konforlu yaşam ortamları sunmaya yardımcı olma,

- İç mekan hava kalitesine olumsuz etkileri olmama olarak sıralanabilir.

Toprak esaslı yapı malzemelerinin ekolojik, çevre dostu malzeme olarak değerlendirilmesindeki unsurlar aşağıda maddeler halinde verilmiştir, (Esin vd., 2008).

- Toprak esaslı malzemeler geri dönüşümlü ve tekrar kullanılabilir,

- Üretimlerinde ham madde olarak doğal malzeme kullanılır,

- Ekonomik olma özelliğine sahiptir,

- Enerjiyi korur. Düşük oluşum enerjisine sahiptirler, yüksek oranda termal özelliğe sahiptirler,

- Çevre ve insan sağlığına zararlı olabilecek emisyonları yoktur. Özellikle, VOCs (volatile organic compounds) ve diğer zararlı kimyasal olan HCFCs (hydrochlorofluorocarbons) veya benzer toksik maddeler içermezler. 
Ülkemizde geleneksel yapılara baktığımızda yerel malzeme kullanımının yaygın olduğu görülmektedir. Toprak esaslı malzemelerin kullanımı başta kırsal bölgeler olmak üzere çok yaygın olarak görülmektedir. Geleneksel yapılarda toprak; sıva, harç ve kerpiç olarak adlandırılan duvar bloğu şeklinde kullanıımıştır. Bu malzemenin yaygın kullanımının birçok nedeni vardır. Yerel olması, ucuz olması, kolay üretilebilir ve ısı depolama özelliğinin olması gibi özellikler bunların bazılarıdır. Ayrıca tamamen geri dönüşümlü ve zehirli gaz salınımı yapmayan, ateşe dayanıklı bir malzeme olduğu da unutulmamalıdır. Bu avantajlarının yanında bir takım zaafları da olan bu malzeme geliştirilmeye son derece yatkın bir malzemedir. Ülkemizde kırsal bölgelerde yaşayan insanlar bu malzemeyi yeteri kadar iyi bilmedikleri için hasarlı yapılarında günümüzün çağdaş malzemesi olarak bilinen çimento esaslı yapı malzemelerini kullanmayı tercih etmektedir. Çimento esaslı yapı malzemeleri uygulamada daha hızlı olma imkanı tanımakla birlikte ciddi yapı fiziği sorunlarına yol açar ve maliyeti de arttırmaktadır. Özellikle kırsal bölgelerde yerel malzeme kullanımı ve geleneksel yapı özelliği taşıyan yapılarda da özgün malzemelerin kullanımına yönelik yapılan teşebbüsler çok daha değerlidir.

Bu makalede incelenen, Bilecik ili, Gölpazarı ilçesinde bulunan bir dağ köyü olan Tongurlar köyünde yaklaşık 150 yıllık geleneksel yapılar bulunmaktadır, Şekil 1,2. Bu yapıların ahşap taşıyıcı sisteme sahip olduğu ara dolgu olarak kerpiç blok ve duvarda sıva, harç olarak da toprak esaslı malzemelerin kullanılmış olduğu tespit edilmiştir. Bu proje kapsamında toprak esaslı malzemeler üzerinde planlanan deneysel çalışmalar iTÜ Mimarlık Fakültesi Yapı Malzemesi Laboratuvarı ile işbirliği sonucunda yapılmıştır. Deneysel çalışmalar 3 adımda planlanmıştır. 1. Adım; yerinde gözlem ve inceleme, 2. Adım; özgün malzemelerin laboratuvar ortamında araştırılması, 3.Adım; toprak esası malzemelerin niteliklerinin iyileştirilmesi, şeklindedir.

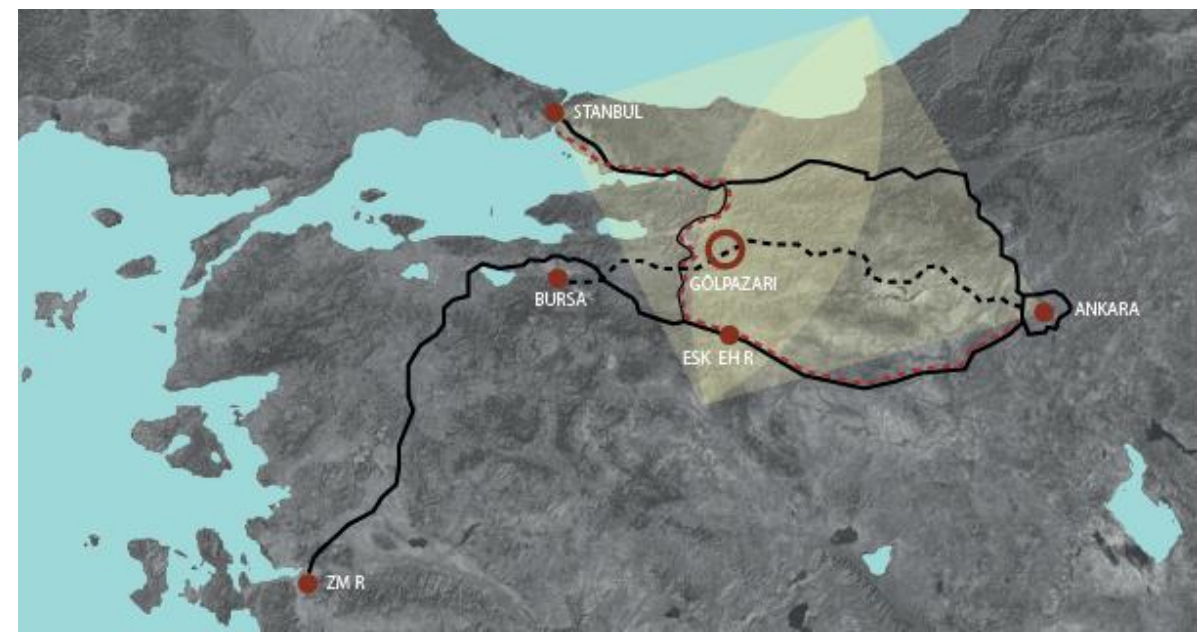

Şekil 1. Bilecik Gölpazarı İlçesinin Çevre Yollar İle İlişkisi,(Arpacıoğlu et al., 2016)

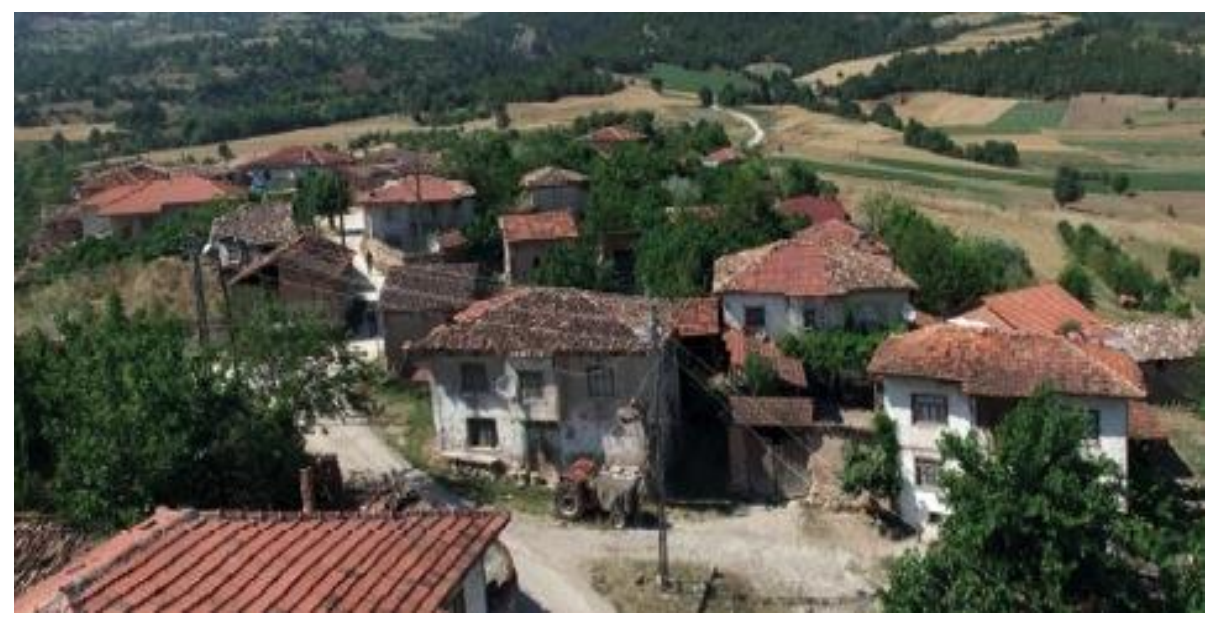

Şekil 2. Bilecik Gölpazarı ilçesi Tongurlar Köyü Genel Görünüm.

Tongurlar Köyü malzeme kullanımında homojen bir karakter göstermektedir. Yerleşim dokusunun tamamında kullanılan malzeme kerpiçtir. Köyde kış mevsiminde yaşayan çok az aile olmasına rağmen, 
yaz mevsiminde yazlık olarak kullanan çok aile vardır. Ancak, konutlar genellikle eski, yani mevcut haliyle kullanıldığı için kullanıcıların ihtiyaçlarına yeterince cevap verememektedir. Bu amaçla konutların rehabilitasyonu amacıyla, malzemelerin de iyileştirilmesi gerekmektedir, Şekil 3.

Bu amaçla;

- Farklı yapılardan kerpiç örnekleri alınmıştır. Alınan örnekler üzerinde kimyasal, fiziksel ve mekanik analizler yapılmıştır.

- Kerpiç üretiminde kullanılan toprak türlerinin belirlenebilmesi için yakın çevreden toprak örnekleri alınmıştır. Bu örneklerin kimyasal özellikleri belirlenmiştir.

- Malzemenin sürdürülebilirliğinin ve iklim koşullarına karşı dayanıklılığının arttırılabilmesi için geliştirilmesi öngörülmektedir. Bu amaçla mevcut malzeme analizlerine göre durum değerlendirmesi yapılıp, mevcut koşullara göre kerpiç malzemenin ve üzerine gelebilecek dış sıva için malzeme önerileri geliştirilmiştir. Bu öneriler yine kerpiç malzeme ve üzerine toprak esaslı sıvanın geliştirilmesi şeklinde olmuştur.

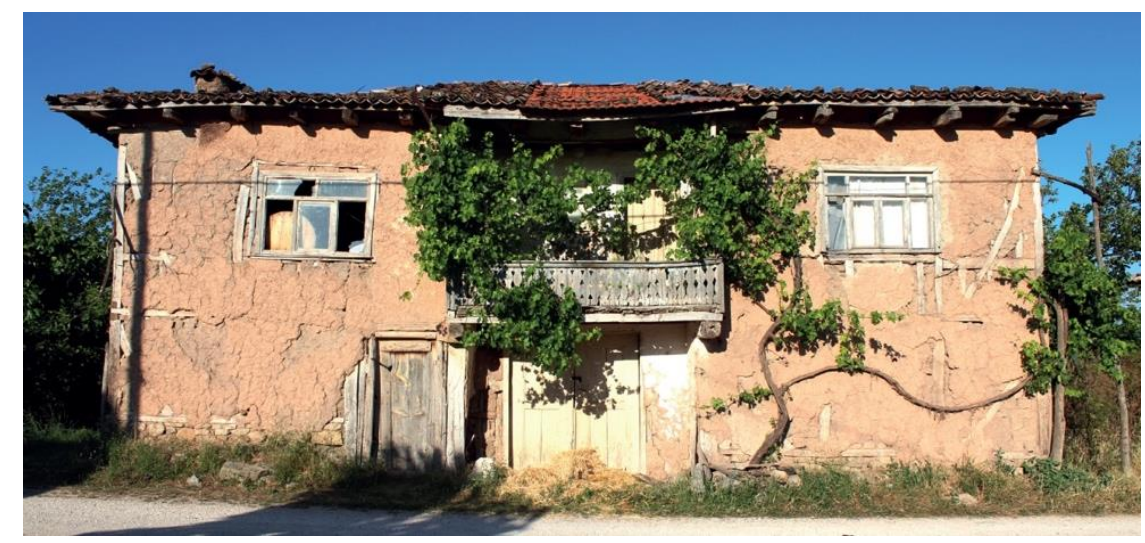

Şekil 3. Bilecik Gölpazarı Tongurlar Köyü'nde bir ev

\section{Deneysel Çalışmalar}

Proje kapsamında planlanan deneysel çalışmalar için belirlenen yapılardan özgün malzeme örnekleri belirli bir sistematik içinde, deneyler için yeterli olacak boyut ve miktarlarda alınmıştır. Alınan özgün örnekler koruma ilkeleri bağlamında belgelenmiştir. Yapılan çalışmalar aşağıdaki bölümlerde anlatılmaktadır.

\section{1. Örnek alma çalışmaları}

Tongurlar Köyü'nde belirlenen birkaç geleneksel yapıdan, kerpiç blok, toprak sıva ve harç örnekleri alınmıştır. Alınan örneklerin bir kısmı hasarlı bir kısmı sağlam durumdadır. Hasarlı örneklerin hasar nedenleri araştırılırken sağlam örneklerde de karakter özelliklerini belirleme deneyleri yapılmıştır ( Şekil 4).
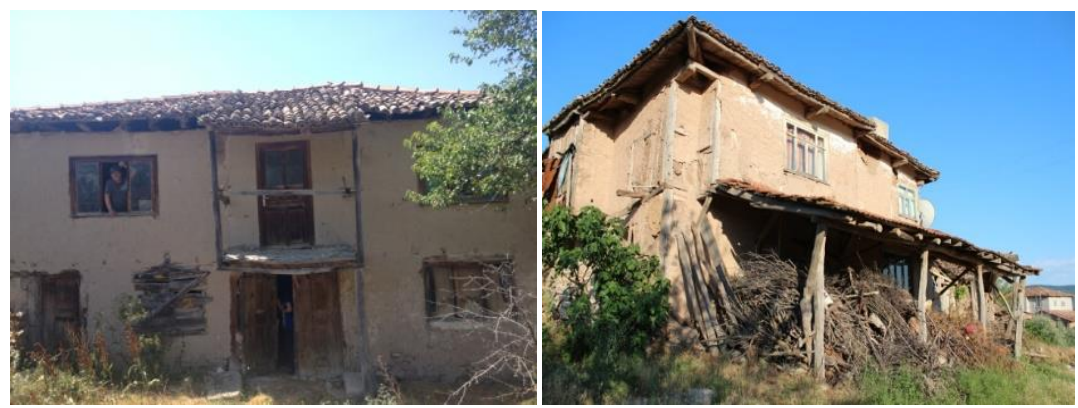

Şekil 4. Tongurlar Köyü'nde seçilen geleneksel yapılardan görüntüler

Geleneksel yapıların çoğu konut yapılarıdır ancak bir adet toprak malzemenin de kullanılmış olduğu okul yapısı vardır. Aşağıda okul yapısından detay görüntüler vardır. En çok hasarlı olan okul yapısıdır. 
Zamanında birçok onarımlar geçirmiş olan bu yapı sadece çevresel etkilere maruz kalmamış yanlış ve uyumsuz malzeme kullanılarak yapılan onarımların da kurbanı olmuştur.

Toprak esaslı malzemeler çok değişken davranışlarda bulunabilir. Hammadde türü ve katılan katkıların etkileri çok fazla olmaktadır. Toprağın içindeki kilin türü, saman gibi lifsel katkıların boyut ve oranları toprak malzemenin performansını doğrudan etkiler, (Koçu, 2006;Ozgunler, 2011). Ayrıca, bu malzemeye katılan alçı, kireç gibi katkılar da toprak malzemenin davranışını değiştirir. Bu bağlamda literatürde çok sayıda bilimsel çalışma yer almaktadır, (Kafescioglu, 1985; Ozgünler vd., 2011). Bölgeden bölgeye de toprak malzemelerinin katkı türlerinin değiştiği görülmektedir. Bu bölgedeki yapılarda kullanılmış olan toprak malzemenin karakterini belirlemek üzere öncelikle aşağıdaki çalışmalar yapılmıştır (Çizelge 1, Şekil 5).

Çizelge 1. Alınan örneklerin kodlanması

\begin{tabular}{|l|l|l|l|}
\hline $\begin{array}{l}\text { Örnek } \\
\text { No. }\end{array}$ & Yapı Kodu & Örnek Kodu & Tanımı \\
\hline 1 & M1 & M1-1 & İç Sıva \\
\hline 2 & M1 & M1-2 & İç Sıva \\
\hline 3 & M1 & M1-3 & Harç \\
\hline 4 & M1 & M1-4 & Dış Sıva \\
\hline 5 & M1 & M1-5 & Kerpiç Blok \\
\hline 6 & M2 & M2-1 & Kerpiç Blok \\
\hline
\end{tabular}

Özgün malzemelerin karakter özelliklerini belirlemek için yapılan deneysel çalışmalar 3 adımda toplanmış ve aşağıdaki akış şeması halinde gösterilmiştir.

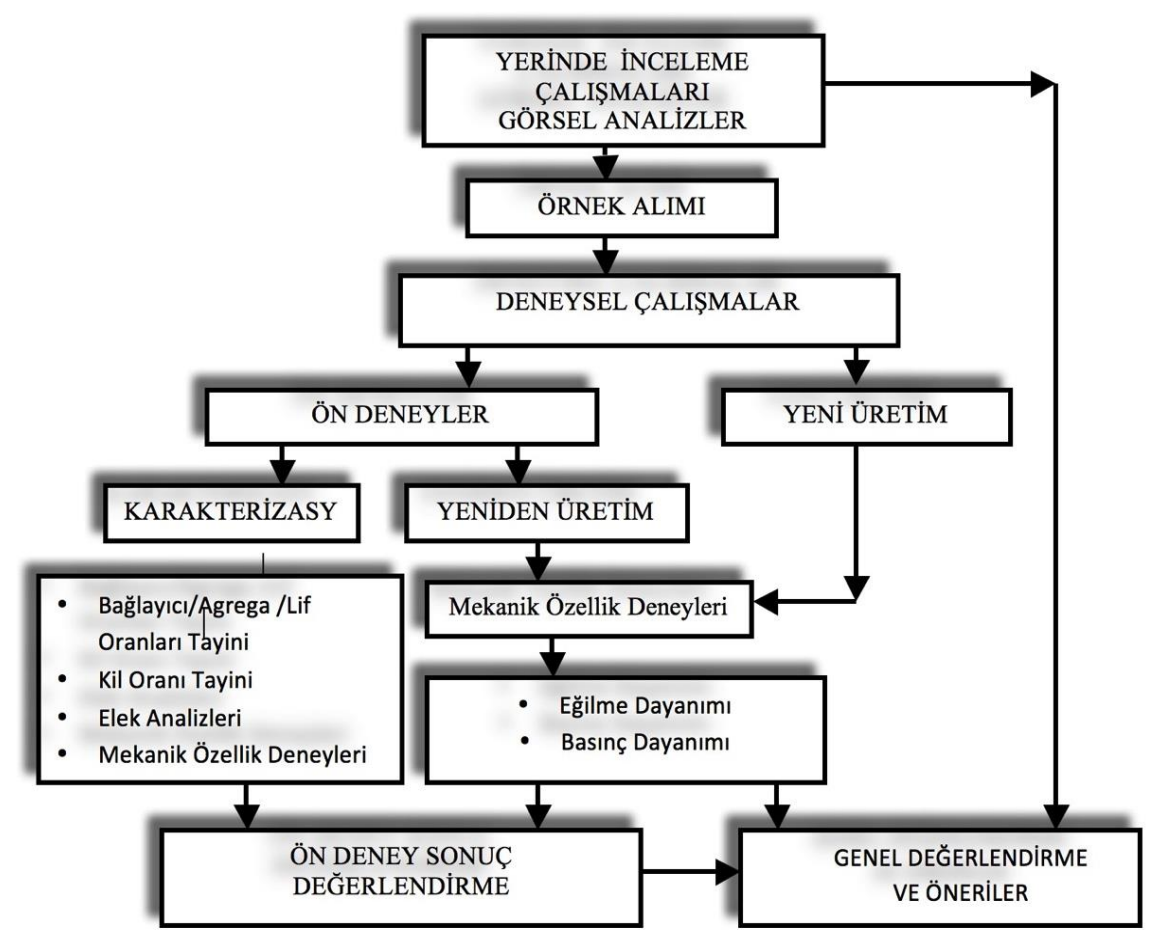

Şekil 5. Deneyleri Gösteren Akım Şeması (Arpacıoğlu, Özgünler, Özgünler, \& Tekin, 2015)

\section{2. Özgün malzemelerde yapılan ön deneyler}

Özgün malzemelerde ilk olarak malzeme karışımlarında kullanılmış olan hammadde türleri ve oranlarını tespit etmeye yönelik kimyasal analizler ile fiziko-mekanik deneyler yapılmıştır. Daha sonra mekanik testlerde kırımış olan kerpiç blok parçaları ezilerek uygun miktarda su katılmış, çürütülerek 
yeniden üretim imkanları denenmiştir. Bu deneme ile toprak malzemenin geri dönüşüm özelliği irdelenmiştir. Deney sonuçları aşağıdaki bölümlerde gösterilmiştir.

\subsubsection{Toprak malzemelerin özelliklerinin belirlenmesi}

Gerek kerpiç gerekse toprak sıvalar kompozit malzeme özelliği taşırlar. Bu malzemelerin içerisinde bağlayıcı olarak kil, agrega olarak da kum vardır. Ayrıca lifsel katkı olarak bol miktarda saman bulunmuştur. Deney sonuçları aşağıdaki grafiklerde gösterilmiştir.

Binder ratio, bağlayıcı olarak bulunan kil malzemenin bulunma oranını, agregate ratio, toprak içinde bulunan kum oranını, fiber ratio, saman oranını ifade etmektedir, Şekil 6.

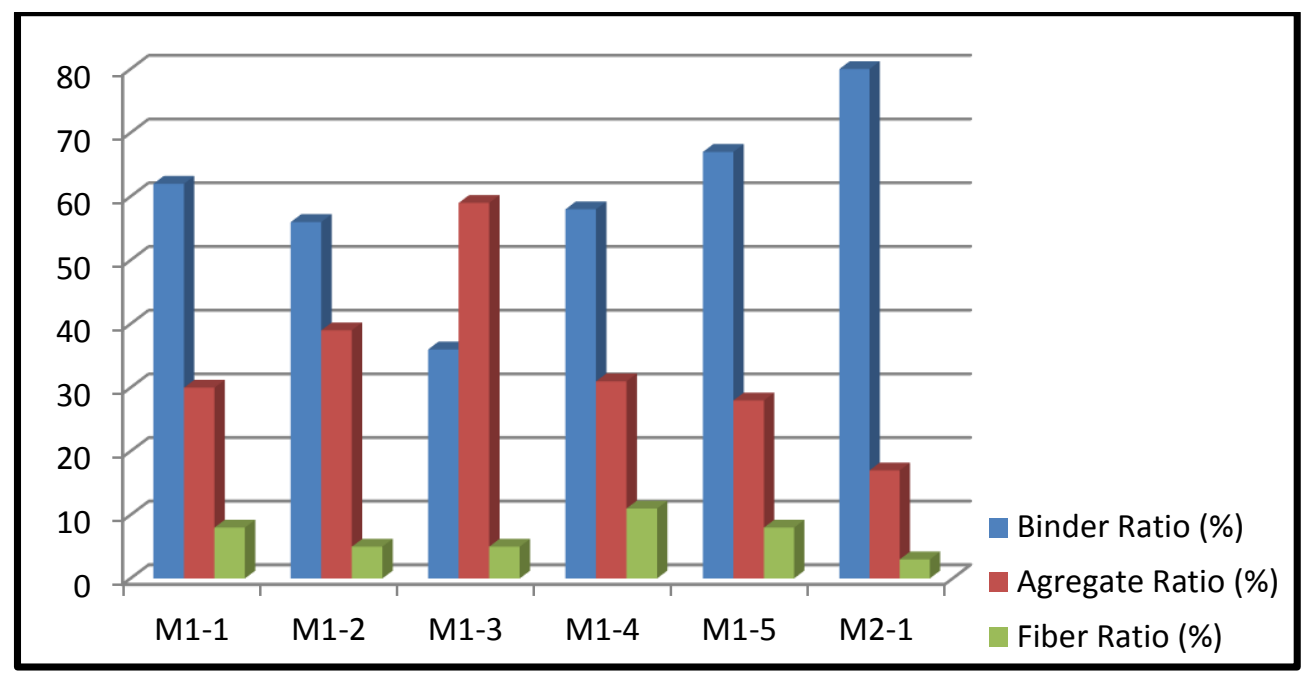

Şekil 6. Toprak esaslı malzemelerde bulunan ham madde oranları

Kerpiç, sıva (dış-iç) ve harç örneklerinde bulunan agregaların dane boyutlarını gösteren granülometri eğrileri aşağıdaki şekilde verilmiştir.

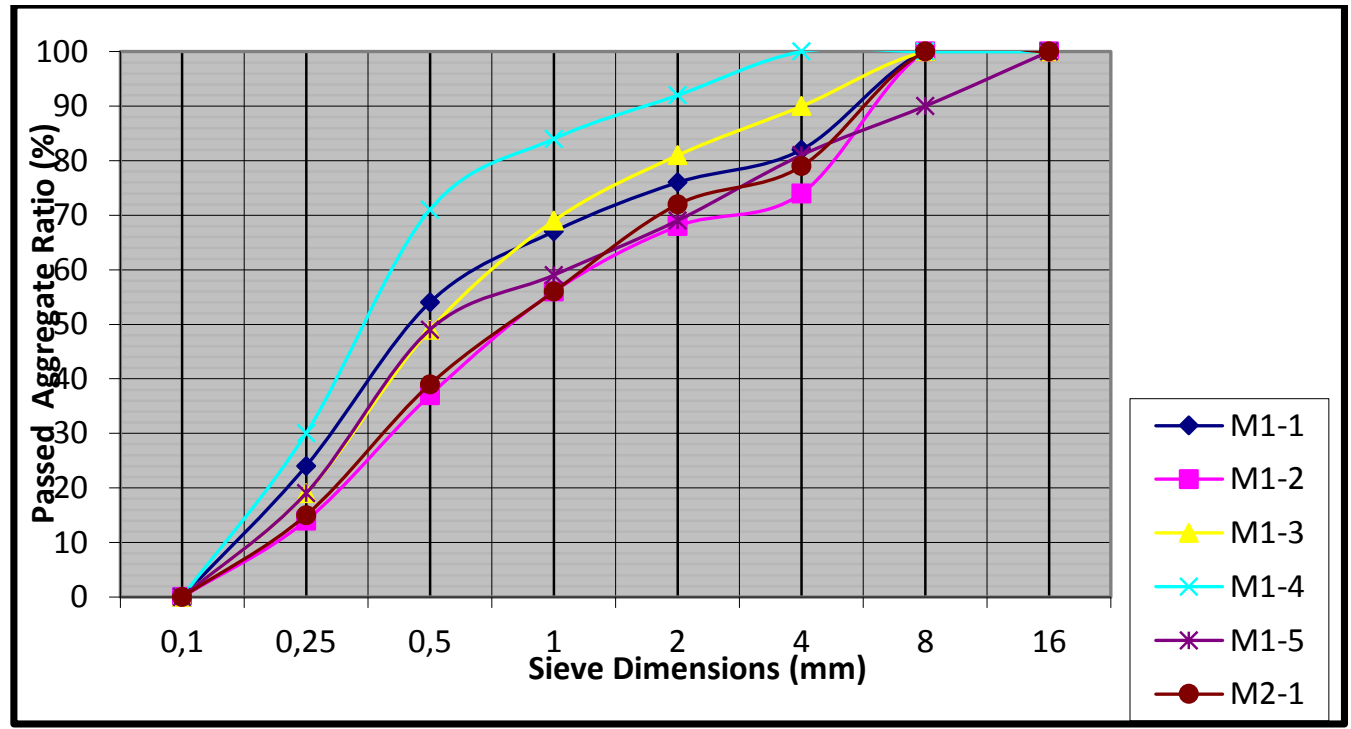

Şekil 7. Örneklerde bulunan agreganın granülometri eğrileri

\section{Toprak malzemede kil tipinin belirlenmesi:}

Bölgeye özgü toprak malzemenin kullanılmış olduğu malzeme örneklerinde kil türünün tespiti için SEM-EDS analizleri yapılmıştır. Bu analiz sonucuna göre kil tipinin smektit ve kaolinit olduğu belirlenmiştir. Bruce King'in yapmış olduğu bir çalışmada, toprak malzemenin kalitesi içerisinde bulunan kil türüne göre değişiklik gösterdiği ifade edilmektedir. Bu çalışmada, toprak malzeme üretiminde en iyi kil türlerinin smektit ve kaolinit olduğu yer almaktadır, (King, 2010). 


\section{Kerpiç örneklerinin mekanik özellikleri:}

Yapılardan alınan özgün kerpiç bloklarda eğilme dayanımı ile eğilmede çekme deneyinde kırılan parçalarda basınç dayanımı deneyleri yapılmıştır. Deney sonuçları 6'şar örneğin ortalaması alınarak verilmiştir. Örneklerin boyutları; 9/14/27 cm.'dir.

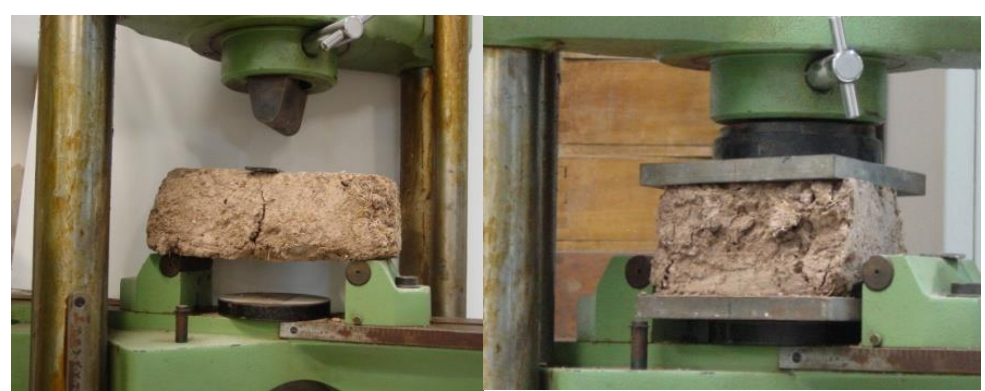

Şekil 8. Kerpiç örneklerin mekanik deney görüntüleri

Çizelge 2. Kerpiç örneklerin ortalama mekanik deney sonuçları

\begin{tabular}{|l|l|l|}
\hline Örnek & $\begin{array}{l}\text { Eğilmede Çekme } \\
\text { Dayanımı } \\
\text { (MPa) }\end{array}$ & $\begin{array}{l}\text { Basınç Dayanımı } \\
\text { (MPa) }\end{array}$ \\
\hline $\begin{array}{l}\text { Kerpiç, M1 } \\
\text { Grubu }\end{array}$ & 0,2 & 0,9 \\
\hline $\begin{array}{l}\text { Kerpiç, M2 } \\
\text { Grubu }\end{array}$ & 0,5 & 1,5 \\
\hline
\end{tabular}

Özgün toprak esaslı malzeme örneklerinde kil, kum ve saman dışında bir katkı maddesi bulunmamıştır. Ayrıca, gevşek yapılı olan örneklerde mekanik dayanımları da düşük bulunmuştur. Her ne kadar kil türü iyi olsa da diğer malzemelerin uygun (ideal) oranlarda olmayışı ve gevşek yapılı olması malzemenin performansını düşürmektedir.

\subsubsection{Toprak esaslı malzemelerin geri dönüşüm çalışmaları}

Bölgede yapılan alan çalışmalarında, geleneksel kerpiç malzemenin kalıplama teknolojisinde farklılıklar olduğu belirlenmiştir. Bu nedenle, çalışmanın bu bölümünde kerpiç örneğinin kırılan parçaları su ile çürütülmüş, dinlendirilmiş ve tekrar kalıplara dökülerek yeniden üretim yapılmıştır. Doğası gereği toprak yapı malzemesi yeniden kullanıldığı zaman performansında bir düşüklük göstermemektedir. Fakat malzemenin kalıplama teknolojisi bu performansı etkilemektedir. Günümüz şartlarında yenilenen bir binada mevcut malzemenin yeniden kullanımı ya da güçlendirilerek kullanımı düşünüldüğünde olası dayanım farklılıklarını değerlendirmek açısından aşağıdaki testler yapılmıştır. Bu bölümdeki çalışmalar mukavemet açısından değerlendirilmiş, suya dayanım ayrı bir bölüm olarak ele alınmıştır.

Geri dönüştürülen malzeme ile prizmatik numuneler hazırlanmıştır. Hazırlanan numunelerin bir kısmı laboratuvar ortamında kurutulmuş, diğer kısmı ise $50^{\circ} \mathrm{C}^{\prime}$ lik etüvde kurtulmuştur. Aynı oranda basınç ile sıkıştırılan ve kalıplanan örnekler farklı koşullarda kurutulmuş ve sonuçları aşağıdaki çizelgede gösterilmiştir.

Çizelge 3. Geri dönüştürülmüş kerpiç örnekler ile özgün kerpiç örneklerin mekanik özelliklerinin karşılaştırılması

\begin{tabular}{|l|l|l|}
\hline Örnekler & $\begin{array}{l}\text { Eğilmede Çekme } \\
\text { Dayanımı } \\
\text { (MPa) }\end{array}$ & $\begin{array}{l}\text { Basınç Dayanımı } \\
\text { (MPa) }\end{array}$ \\
\hline Özgün Kerpiç & 0,2 & 1,0 \\
\hline OKN & 1,0 & 2,0 \\
\hline EKN-50 & 1,3 & 2,5 \\
\hline
\end{tabular}

OKN: Laboratuvar ortamında kurutulan

EKN-50: $50^{\circ} \mathrm{C}$ etüvde kurutulanlar 

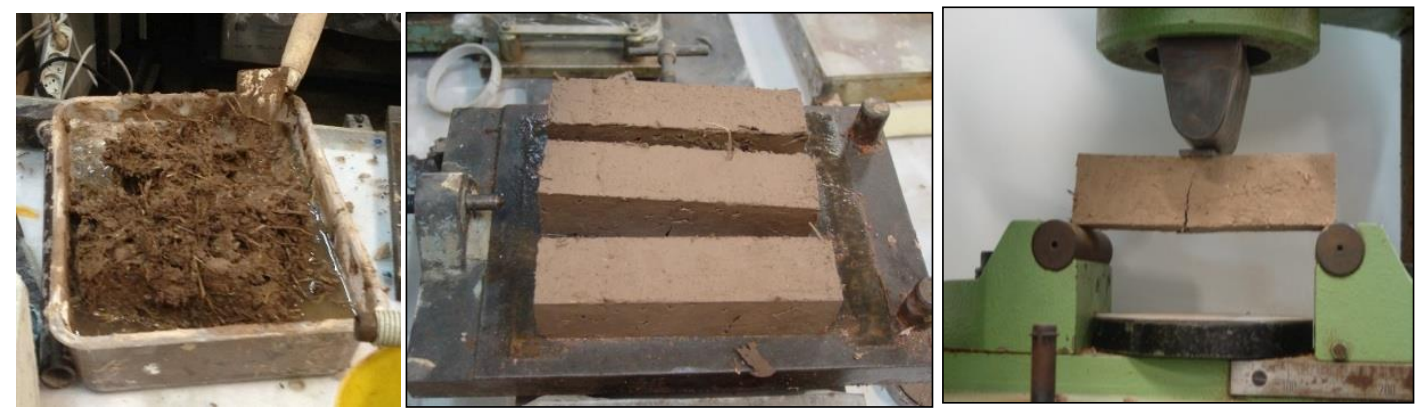

Şekil 9. Geri dönüştürülen toprak esaslı malzemelerin mekanik deney görüntüleri

Sonuçta, kalıplama ve kurutma tekniğine bağlı olarak mekanik özelliklerde bir artış görülmüştür.

\section{Sonuç ve Öneriler}

Kırsal alandaki geleneksel mimari her geçen gün daha fazla risk altındadır. Bu binalar yerine daha az sürdürülebilir binalar yapılmakta, ulaşım imkanlarımız arttıkça, kırsal alanlar üzerinde şehir inşaat kültürünün etkisi artarak geleneksel mimarinin yok olması ile karşı karşıya kalmaktayız. Halbuki geleneksel yapım yöntemi ve kültürünü üzerinde barındıran bu mimarinin korunması için özgün malzemenin çağdaş gereksinimlere cevap verecek, enerji girdisi düşük (green restorasyon) ve geleneksel mimariye uygun yeni yapılaşma için de kullanılabilme potansiyeline sahiptir. Böylece yeni yapım olsa bile kırsal alana uygun sürdürülebilir ve çağdaş bir mimari olanağı sağlanabilir.

Bu bakış açısı ile yapılan tüm deneysel çalışmalar sonucunda; bölüm II. deki toprak malzemenin yeniden kullanımında kalıp teknolojisinin malzemenin mekanik özelliğini 2 kat arttırdığı belirlenmiştir. Ancak suya dayanımın sağlanabilmesi için mutlaka güçlendirme parametresine ihtiyaç olduğu belirlenmiştir. Bu sebeple, kireç gibi uyumlu olabilecek malzemelerin katılması da malzemenin performansını arttıracaktır. Bunların dışında yapısal detaylar ile de hava koşullarından koruyacak önlemler alınması da büyük önem taşımaktadır.

Geleneksel malzemenin güçlendirilerek yeniden kullanılması, enerji verimliliği dışında bu mimarinin sürdürülebilirliği açısından da önemlidir. Bu bakış açısı ile yeniden ele alınmış toprak malzemenin, geleneksel mimari kültürünün devamını sağlayacağı ve geçmişi geleceğe taşıyacağı ve doğası gereği toprak malzemenin sağlıklı olması gelecekte de ihtiyaç duyduğumuz sürdürülebilirlik gereksinimini de karşılayacaktır. Tüm bu deneysel çalışmalar, göstermiştir ki algılananın aksine toprak yapı malzemesi yeniden mimaride kullanım alanı bulmakta sürdürülebilirliğini kanıtlamaktadır.

\section{Teşekkür}

Bu çalışmanın oluşturulmasında değerli katkıları olan, Yrd. Doç. Dr. Ümit Arpacıoğlu, Doç. Dr. Seden Acun Özgünler ve Doç. Dr. Çiğdem Tekin'e çok teşekkür ederim.

\section{Kaynaklar}

Arpacıoğlu, Ü. (2016), “Kırsal Sürdürülebilirlikte Yeni Bir Model: Köyünü Yaşat Projesi” Yapı Dergisi, Sayı 421, Aralık 2016, S132-138, ìstanbul.

Arpacıoğlu, Ü. (2006). " Geçmişten Günümüze Kerpiç Malzeme Üretim Teknikleri ve Güncel Kullanım Olanakları", 3. Ulusal Yapı Malzemesi Kongresi, Bildiri, 15-17 Kasım, s.667-679, ìstanbul.

Arpacıoğlu, Ü., Özgünler, S., Özgünler, M., \& Tekin, Ç. (2015). Kerpiç malzemenin modern kullanım olanaklarının sağlanması için geliştirilmesi. MSGSU BAP Projesi, İstanbul.

Esin T., Yüksek i. (2008). " A Study on Ecological Properties of Building Materials Used in Traditional Buildings (in Turkey)", Emerald Insight journal Vol. 26 Iss 5/6 pp. 229 - 241.

Kafesçioğlu, R., Gürdal, E.. (1985). "Çağdaş Yapı Malzemesi, Alker", iTÜ yayınları., s. 40, İstanbul.

King, B. (2010). "Toprak Mimarisinin Yeniden Doğuşu", Mimarlıkta Malzeme, Yıl:5, Sayı:17, s.62-80, Ekim, İstanbul.

Koçu, N., Koçu, Ş. (2006). "Beyşehir Kurucuova Yöresi Geleneksel Kerpiç Evleri ve Özellikleri", I. Uluslararası Beyşehir ve Yöresi Sempozyumu, Bildiriler Kitabı, s.508-516, Konya. 
Morton T., Stevenson F., Taylor B., Smith C. (2005). " Low Cost Earth Brick Construction: Monitoring and Evaluation", Arc. Architects, ISBN 0-9550580-0-7.

Ngowi, A.B. (2001). "Creating Competitive Advantage By Using Environment-Friendly Building Processes", Building and Environment, Vol. 36 No. 3, pp. 291-298.

Olgyay, V. and Herdt, J. (2004) "The Application of Ecosystems Services Criteria for Green Building Assessment", Solar Energy, Vol. 77 No. 4, pp. 389-98.

Özgünler Acun S., Gürdal E. (2011). "Dünden Bugüne Toprak Yapı Malzemesi: Kerpiç", Restorasyon/ Konservasyon Çalışmaları Dergisi, sayı: 9, s. 29-48.

Torgal P. F., Jalali S. (2012). "Earth Construction: Lessons From The Past For Future Eco-Efficient Construction", Construction and Building Materials 29, pp. 512-519. 